\title{
Association of vitamin D with tuberculosis patients of Sargodha, Pakistan
}

\section{Saima Saleem ${ }^{1}$, Waqas Ahmad Khan ${ }^{1 *}$, Basharat Ali $^{2}$, Hamid Mustafa ${ }^{3}$, Tanveer Hussain ${ }^{4}$, Ali Raza Awan ${ }^{5}$, Shakir Hafeez ${ }^{1}$, Arif Malik ${ }^{6}$ and Ahmad Mukhtar Khalid ${ }^{1,6}$}

1. Department of Biotechnology, University of Sargodha, Sargodha-Pakistan

2. Department of Family Medicine, University of Health Sciences, Lahore-Pakistan

3. Department of Livestock Production, University of Veterinary and Animal Science, Lahore-Pakistan

4. Department of Molecular Biology \& Biotechnology, Virtual University of Pakistan

5. Institute of Biochemistry \& Biotechnology, University of Lahore, Lahore-Pakistan

6. Institute of Molecular Biology \& Biotechnology, University of Lahore, Lahore-Pakistan

*Corresponding author's email: waqaskhang@gmail.com

Citation

Saima Saleem, Waqas Ahmad Khan, Basharat Ali, Hamid Mustafa, Tanveer Hussain, Ali Raza Awan, Shakir Hafeez, Arif Malik and Ahmad Mukhtar Khalid. Association of vitamin D with tuberculosis patients of Sargodha, Pakistan. Pure and Applied Biology. Vol. 7, Issue 1, pp236-242. http://dx.doi.org/10.19045/bspab.2018.70028

Received: 12/01/2018

Revised: 07/02/2018

Accepted: 10/02/2018

Online First: $15 / 02 / 2018$

\section{Abstract}

Deficiency of vitamin D (25-hydroxycholecalciferol) has long been concerned in activation of tuberculosis (TB). Pakistan stands fifth among 22 countries that have the highest TB incidence. Vitamin D influences the immune response to tuberculosis and vitamin D deficiency has been associated with increased risk of tuberculosis in different populations. This study was designed to show the relationship between vitamin D level (deficiency) and risk of tuberculosis. Eighty five blood samples of tuberculosis patients were taken from District Head Quarter (DHQ) Hospital, Sargodha. ORGENTEC ELISA Kit was used for vitamin D quantification. Mean vitamin D level were $13.9 \pm 1.68 \mathrm{ng} / \mathrm{mL}$ in control and $9.3 \pm 1.38 \mathrm{ng} / \mathrm{mL}$ in TB patients. Out of 85 patients 82 patients showed vitamin D level less than $12 \mathrm{ng} / \mathrm{mL}$. Vitamin D deficiency was seen in almost $96 \%$ of patients as compared to control. Female patients $(9.05 \pm 1.55 \mathrm{ng} / \mathrm{mL})$ also have significantly lower vitamin D level as compare to male patients $(9.79 \pm 1.34 \mathrm{ng} / \mathrm{mL})$. These findings warrant further studies that the vitamin $\mathrm{D}$ supplementation may have the role in the treatment and prevention of tuberculosis.

Keywords: ELISA; Pakistan; Tuberculosis; Vitamin D

\section{Introduction}

Tuberculosis (TB) is a transmittable bacterial infectious disease that is top ranked among world's deadliest contagious diseases [1]. Numbers of cases of tuberculosis are increasing in all developed, underdeveloped and developing countries that shows the impact of tuberculosis on world's health [2]. Risk due to tuberculosis to global health can be easily understood by the fact that one third of world's population is infected with causative agent of TB, mycobacterium tuberculosis (MTB) [3]. It infects human and non-human mammals [4]. M. tuberculosis, 
M. bovis, M. affricanum, M. cannitii and M. microti and some closely related organisms make up the M. tuberculosis complex (MTB complex). The Mycobacterium tuberculosis mostly affects the lungs but can also affect any part of the body such as kidney, spine and brain [5]. In the past it was considered the leading cause of death in United States from infection [6]. Approximately $95 \%$ cases of tuberculosis occur in developing countries with highest rates seen in South East Asia, Sub-Saharan Africa and China [7]. Pakistan stands fifth among 22 countries that have the highest TB incidence [8]. In Pakistan estimated new cases were 510,000 emerging each year, and approximately 15,000 developing drug resistant TB cases every year [9]. World Health Organization estimated that 9.6 million people become infected with tuberculosis and 1.5 million people died from tuberculosis in 2014 and approximately 1 million children become ill with TB and 140000 died from TB disease [10]. China and India together accounted for more than one-third of all new TB cases in 2008 [11]. In 2015, 10.4 million people fall victim to $\mathrm{TB}$ and 1.8 million died from $\mathrm{TB}$ disease [12]. Over $95 \%$ of deaths due to TB occur in below and middle-income countries [2].

Active form of vitamin D had a complex action on immune system, by modulating and inhibiting the MTB growth. Low level of vitamin $\mathrm{D}[<20 \mathrm{ng} / \mathrm{mL}]$ is commonly found all over the world, especially in economically developing countries [13]. Different findings showed that macrophages were most effectual in producing cathelicidin an antimicrobial peptide LL-73 after infection with tuberculosis, suggesting that cathelicidin from macrophages was major component in the innate immune response during infection [14]. In 2006, Liu suggested that transcription of cathelicidin peptide was mediated by the activation $25(\mathrm{OH}) \mathrm{D}$. Toll like receptor (TLR) activation by microbial product result in increased the conversion of inactive 25- hydroxyvitamin $\mathrm{D}$ to its active form 1, 25-hydroxyvitamin D. Activation of TLR may increase the production of cathelicidin and defensin-2, these two peptides are strongly upregulated by the 1,25 hydroxyvitamin D [15]. Vitamin D influences the immune response to tuberculosis and vitamin D deficiency has been associated with increased risk of tuberculosis in different populations. It is clear from above discussion that there is a strong relationship between level of vitamin $\mathrm{D}$ and immune response thus affecting progression of tuberculosis, so this study was designed to show the relationship between vitamin D level (deficiency) and risk of tuberculosis.

\section{Materials and methods}

The study was carried out by collecting blood samples of tuberculosis patients from DHQ Hospital, Sargodha. This work was approved by ethical review committee, Department of Biotechnology, University of Sargodha, Sargodha. Blood samples of eighty five newly diagnosed patients of tuberculosis patients between 16 to 70 years of age were taken randomly along with eighty five control subjects. The samples were collected by following the exclusion criteria (Infant and adult under 16, significant smoker, clinically obese and patients with kidney or thyroid disease) and inclusion criteria (Patients above age 16, negative serology for HIV, diagnose with TB for the first time and smear positive for acid fast bacilli) of TB patients. Vitamin D level less than $12 \mathrm{ng} / \mathrm{mL}$ was considered as vitamin $\mathrm{D}$ deficiency in TB patients. TB patients asked to fill the Performa about their age, sex, occupation, job description, smoking, dietary habits and excluded from the study those who has bone disease, kidney problems, HIV infected people.

TB patient's blood was centrifuge to separate the serum within one hour after 
collection. The patients were diagnosed by the identification of acid fast bacilli in sputum samples. The vitamin D quantification was done by using ELISA technique [16]. ORGENTEC ELISA Kit was used for vitamin D quantification. Statistical interpretation of data was performed using statistical package for social sciences (SPSS). Results were expressed as mean, standard deviation and percentage for the categorical data. The Independent Samples $t$ Test was used to compare the means of controls and cases. $\mathrm{P}$ value less than 0.05 was taken as significant.

Results

The vitamin D level was insufficient in TB patients as well as in control group $(<$ 20ng/mL). Mean vitamin D level in TB patients were lowered as compare to control group (Figure 1). Means vitamin D level in the TB patients and control were $13.9 \pm 1.68$ $\mathrm{ng} / \mathrm{mL}$ and $9.3 \pm 1.38 \mathrm{ng} / \mathrm{mL}$ respectively and $\mathrm{p}$-value is significant $(\mathrm{p}<0.05)($ Table 1$)$.

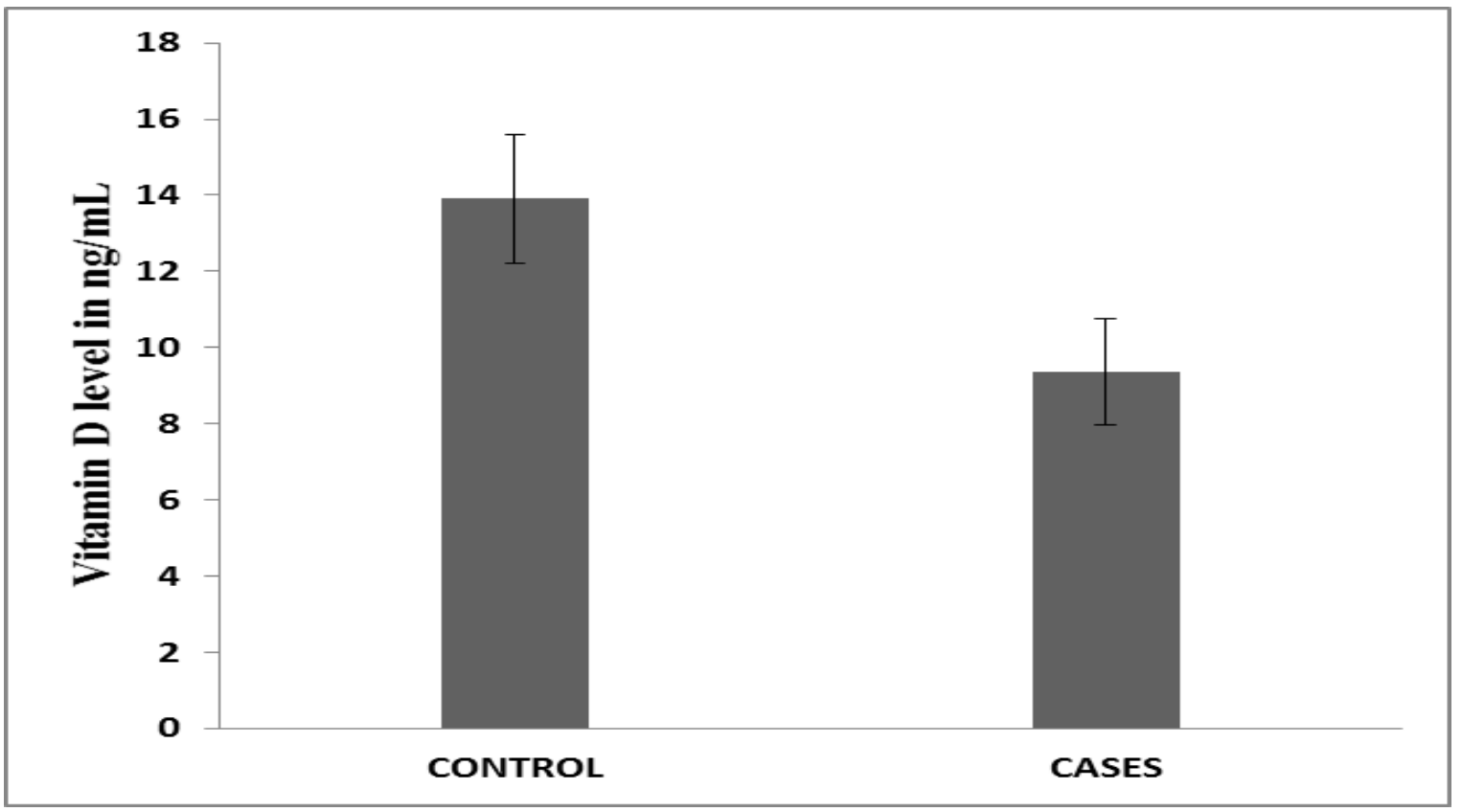

Figure 1. Mean vitamin D level in TB patients and control by independent sample $t$ - test and $p$ value 0.00

Table 1. Different variables in cases and control

\begin{tabular}{|l|l|l|}
\hline Variables & Cases $\mathrm{n}=85$ & Control $\mathrm{n}=85$ \\
\hline Age & $16-65$ years & $16-70$ years \\
\hline Males & 45 & 40 \\
\hline Females & 40 & 45 \\
\hline Mean vitamin D level & $9.35 \mathrm{ng} / \mathrm{mL}$ & $13.90 \mathrm{ng} / \mathrm{mL}$ \\
\hline S.D & 1.38 & 1.68 \\
\hline Vitamin D deficiency & $96 \%$ & $4 \%$ \\
\hline
\end{tabular}

The TB patients were divided into four different age groups to showed the vitamin D level in different criteria $<10 \mathrm{ng} / \mathrm{ml}$, between 10-12ng/mL, < 12ng/mL (Table 2). Among 
tuberculosis patients $69 \%$ had vitamin D level less than $10 \mathrm{ng} / \mathrm{ml}$ and 59 patients were included in this group, $27 \%$ had vitamin D level between $10-12 \mathrm{ng} / \mathrm{mL}$ and 23 patients were included in this group. Only $4 \%$ showed the vitamin D level greater than $12 \mathrm{ng} / \mathrm{mL}$ and only 3 patients were included in this group. Deficiency of vitamin $\mathrm{D}$ was seen almost in 96\% tuberculosis patients. Only 4\% showed the insufficient vitamin D level. The vitamin $\mathrm{D}$ deficiency was also seen greater in women than men (Figure 2).

Table 2. Percentage of vitamin $\mathrm{D}$ level in $\mathrm{ng} / \mathrm{mL}$ in different age groups.

\begin{tabular}{|c|c|c|c|c|}
\hline \multirow[b]{2}{*}{ Ages } & \multicolumn{3}{|c|}{ Vitamin D level in $\mathrm{ng} / \mathrm{ml}$} & \multirow[b]{2}{*}{ Total 100\% } \\
\hline & $<10 \mathrm{ng} / \mathrm{ml} 69 \%$ & $10-12 \mathrm{ng} / \mathrm{ml} \mathrm{27 \%}$ & $>12 \mathrm{ng} / \mathrm{ml} \mathrm{4 \%}$ & \\
\hline 16-30 years & 14 & 5 & 2 & 21 \\
\hline 31-45 years & 34 & 12 & 1 & 47 \\
\hline 46-60 years & 9 & 5 & 0 & 14 \\
\hline 60_75 year & 2 & 1 & 0 & 3 \\
\hline Total & 59 & 23 & 3 & 85 \\
\hline
\end{tabular}

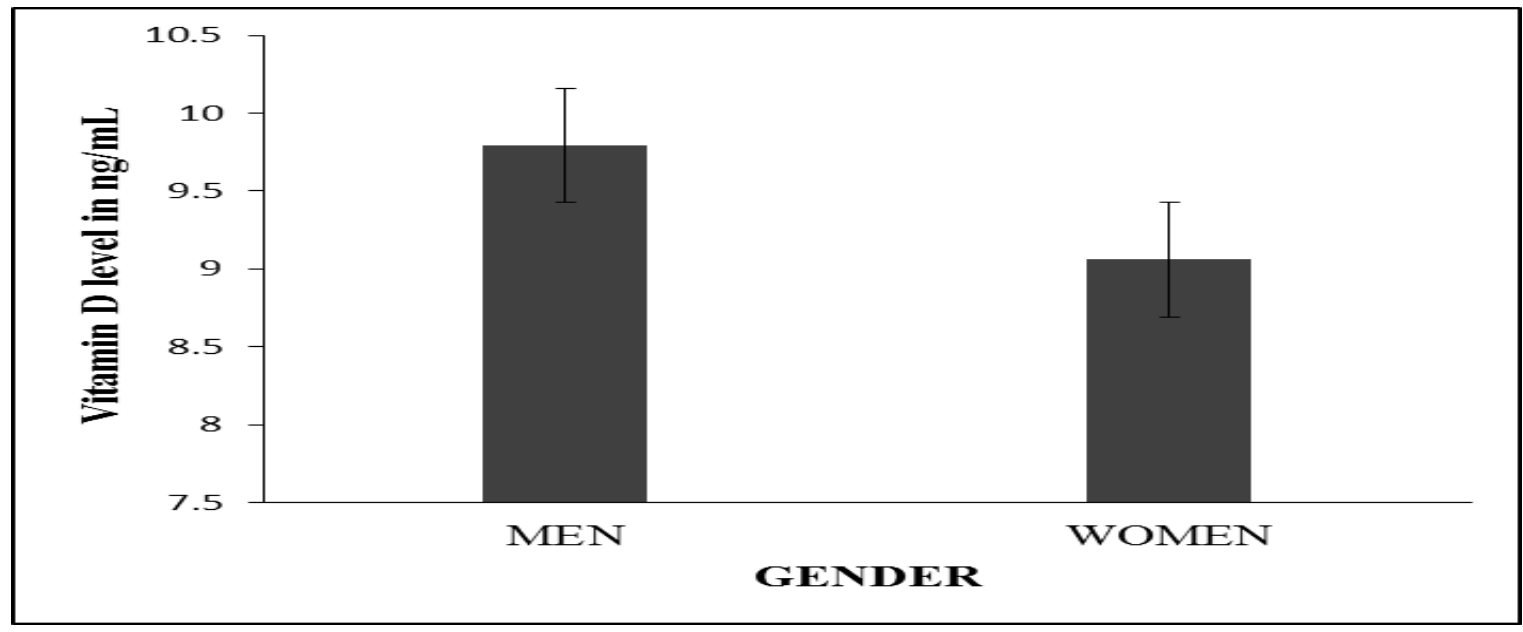

Figure 2. Mean vitamin $D(\mathrm{ng} / \mathrm{mL})$ level in men and women TB patients by independent sample $t$-test and $p$ value 0.02

\section{Discussion}

Tuberculosis is still the major public health problem worldwide [17]. The incident of tuberculosis in Sub-Saharan Africa is 350 per 100,000 as compared to Europe where the incident is 50 per 100,000 and in Pakistan 231 per 100,000 [18]. Approximately 1.7 million people die from TB and the incidence increase every year due to the increasing global population [19]. Tuberculosis is still considered as worldwide health problem in young people. It is highly infectious disease and is generally distributed all over the world [20]. HIV infection is considered as an important threat for developing active TB from latent TB infection. Drug resistance TB makes difficult to treat TB [21]. In earlier ages cod liver oil was used for the treatment of tuberculosis being the rich source of vitamin D [22]. Vitamin D is made by the skin with the help of ultra violet radiation which is the major source for the production of vitamin D and other nutritional sources are yolk, fish, milk and butter. In 2014, 1.2 million people died from tuberculosis [23]. Vitamin D enhances the antimicrobial activity and improves the immune response to tuberculosis and its deficiency is closely 
related to increased progression to active tuberculosis disease [24]. Several recent studies in many populations shows the association of vitamin $\mathrm{D}$ deficiency and increased risk of tuberculosis [25]. Among African immigrants in Australia lower serum vitamin $\mathrm{D}$ level is seen in tuberculosis patients as compared to non-tuberculosis patients [26]. Active form of vitamin D has a diverse action on immune system, by regulating and inhibiting the activity in different ways. Mycobacterium tuberculosis is sensed by Toll like receptor (TRL2) which improve the expression of vitamin $\mathrm{D}$ receptors and CYP27B1 in monocytes. The activation of vitamin $\mathrm{D}$ receptors produced the antimicrobial peptide cathelicidin and killed intracellular MTB. Cathelicidin shows direct antimicrobial effects [27]. The possible association between tuberculosis and vitamin D was first seen before 20 years ago but succeeding studies showed the conflicting finding. But different studies in Gujratian Indians, African residents in India, London and few studies in Pakistan showed that the low vitamin D level caused an increase in progression of tuberculosis [28]

The results of this study are consistent with the previous studies which were done on Pakistan [28], and West African people had showed that low level of vitamin D and high prevalence of TB disease [26]. The study in Egypt showed the plasma level of Vitamin D lower at the time of diagnosis of pulmonary TB [29]. The present study found that vitamin $\mathrm{D}$ deficiency (VDD) was more frequent in tuberculosis patients as compared to the control. Severe vitamin D deficiency $(<10 \mathrm{ng} / \mathrm{mL})$ in tuberculosis patients was seen but this deficiency was not found in healthy persons. In this study eighty five (85) tuberculosis patients were selected. The ages of the patients were 16 to 65 years. The mean vitamin D level in cases is $9.3 \pm 1.38 \mathrm{ng} / \mathrm{mL}$ and control is $13.9 \pm 1.68 \mathrm{ng} / \mathrm{mL}$. The mean vitamin $\mathrm{D}$ level is significantly lowered in cases as compare to the control. The $\mathrm{P}$ value $(p=0.00)$ is also highly significant $(p<0.05)$. In this study it is also found that female patients with tuberculosis have lower vitamin D level as compare to men (As shown in Figure 2). This finding is again consistent with the previous studies in Pakistan which show the statistically significance differences of vitamin D level in women and men [30]. This could be a result of the poor sun exposure in female tuberculosis patients [31]. Similar to the current study, reports from Uganda [32] and Malawi [33] show that Vitamin D deficiency is associated with progression of tuberculosis in TB patients. In healthy individual's insufficient vitamin D level were also observed. Only three healthy individuals out of eighty five showed the vitamin D level less than $12 \mathrm{ng} / \mathrm{mL}$. Despite several limitation in our study such as no information about body mass index, about diet, exposure to sunlight, clothing and relatively small number of participants our findings are supported by several experimental results which shows the low vitamin $\mathrm{D}$ low in $\mathrm{TB}$ patients as compare to control.

\section{Conclusion}

As compared to control subject, vitamin D deficiency was significantly seen in tuberculosis patients. The current study also warranted further studies that whether the vitamin D supplementation can have the role in the treatment and prevention of tuberculosis in developing countries like Pakistan.

\section{Authors' contributions}

Conceived and designed the experiments: WA Khan, B Ali \& AR Awan, Performed the experiments: S Saleem, WA Khan \& A Malik Analyzed the data: S Saleem, WA Khan, S Hafeez, H Mustafa \& T Hussain, Contributed materials/ analysis/ tools: AMr Khalid, A Malik, WA Khan \& S Saleem, Wrote the paper: S Saleem, WA Khan. 


\section{Acknowledgment}

We are thankful to District Head Quarter Hospital, Sargodha for providing samples of TB patients.

\section{References}

1. Dye C \& Williams BG (2010). The population dynamics and control of tuberculosis. Science 328(5980): 85661.

2. World Health Organization (2016). Global tuberculosis report.

3. Onozaki I, Law I, Sismanidis C, Zignol M, Glaziou P \& Floyd K (2015). National tuberculosis prevalence surveys in Asia, 1990-2012: an overview of results and lessons learned. Trop Med Int Health 20(9): 1128-45.

4. Zlot A, Vines J, Nystrom L, Lane L, Behm H, Denny J, Finnegan M, Hostetler T, Matthews G, Storms T \& DeBess E (2013). Diagnosis of tuberculosis in three zoo elephants and a human contact-Oregon 8(64): 1398402.5 .

5. Takahashi $\mathrm{T}$, Tamura $\mathrm{M} \&$ Takasu $\mathrm{T}$ (2012). The PCR-based diagnosis of central nervous system tuberculosis; Tuberc Res Treat 2012: 1-1

6. Contini C, Maritati M, Cultrera R \& Di Nuzzo M (2015). Infections in migrants: global and local epidemiological issues. Annali Online dell'Università di Ferrara 10: 191-233.

7. Mohajan HK (2015). Tuberculosis is a fatal disease among some developing countries of the world. Am J Infect Dis 3(1): 18.275 .

8. World Health Organization (2015). Use of high burden country lists for TB by WHO in the post-2015 era. Geneva: World Health Organization.

9. World Health Organization (2016). Global Tuberculosis Control, http://www.who.int/tb/publications/glob al_report/en/.
10. World Health Organization (2014). Antimicrobial resistance: global report on surveillance. World Health Organization.

11. Barry CE, Boshoff HI, Dartois V, Dick T, Ehrt S, Flynn J, Schnappinger D, Wilkinson RJ \& Young D (2009) The spectrum of latent tuberculosis: rethinking the biology and intervention strategies. Nat Rev Microbiol 7(12): 84555.

12. World Health Organization (2015). Global tuberculosis report Available:http://apps.who.int/iris/bitstre am/10665/191102/1/9789241565059_e ng.pdf? Ua=1.

13. Oren Y, Shapira Y, Agmon-Levin N, Kivity S, Zafrir Y, Altman A, Lerner A \& Shoenfeld Y. (2010). Vitamin D insufficiency in a sunny environment: a demographic and seasonal analysis. Isr Med Assoc J 12: 751-756.

14. Vandamme D, Landuyt B, Luyten W \& Schoofs L (2012). A comprehensive summary of LL-37, the factotum human cathelicidin peptide. Cell Immunol 280: 22-35.

15. Eun-Kyeong J (2010). Innate immunity to mycobacteria: vitamin $\mathrm{D}$ and autophagy. Cell Microb 128(8): 102635.

16. Talat N, Perry S, Parsonnet J, Dawood G \& Hussain R (2009). Vitamin D deficiency and tuberculosis progression. Emerging infectious diseases 16(5): 853.

17. Raviglione M, Marais B, Floyd K, Lönnroth K, Getahun H, Migliori GB \& Chakaya J (2012). Scaling up interventions to achieve global tuberculosis control: progress and new developments. The Lancet 379(9829): 1902-1913.

18. WHO. Burden (2009). Global tuberculosis control: epidemiology, strategy, financing. 187-300. 
19. WHO (2010). Global tuberculosis control-surveillance, planning, financing. Geneva, Switzerland.

20. Gopi PG, Subramani R, Chandrasekaran V, Santha T \& Narayanan PR (2008) Impact of improved treatment success on the prevalence of $\mathrm{TB}$ in a rural community based on active surveillance. Indian J Tuberc 55(1): 22-27.

21. Kruk A, Bannister W, Podlekareva DN, Chentsova NP, Rakhmanova AG, Horban A, Domingo P, Mocroft A, Lundgren JD \& Kirk O (2011) Euro SIDA study group: Tuberculosis among HIV-positive patients across Europe: changes over time and risk factors. AIDS 25: 1505-1513.

22. Grad R (2004) Cod and the consumptive: a brief history of cod-liver oil in the treatment of pulmonary tuberculosis. Pharmacy in history 46(3): 106-20.

23. WHO. Burden (2014). Global tuberculosis control: epidemiology, strategy, financing. 187-300.

24. Arnedo-Pena A, Juan-Cerdan JV \& Romeu-Garcia A (2011). Latent tuberculosis infection, tuberculin skin test and vitamin D status in contacts of tuberculosis patients: a cross-sectional and case-control study, BMC Infect Dis 11: 349.

25. Kim JH, Park JS \& Cho YJ (2014) Low serum 25-hydroxyvitamin D level: an independent risk factor for tuberculosis? Clin Nutr 33(6): 1081-1086

26. Wejse C, Olesen R, Rabna P, Kaestel P, Gustafson P, Aaby P, Andersen PL, Glerup H \& Sodemann M (2007). Serum 25-hydroxyvitamin D in a West African population of tuberculosis patients and unmatched healthy controls. Am J Clin Nutr 86(5): 1376-83.

27. Baeke F, Takiishi T, Korf H, Gysemans C \& Mathieu C (2010) Vitamin D: modulator of the immune system. Curr Opi Pharmacol 10(4): 482-496.

28. Iftikhar R, Kamran SM, Qadir A, Haider E \& Bin UH (2013). Vitamin D deficiency in patients with tuberculosis. J Coll Physicians Surg Pak 23(10): 7803.

29. Edem VF, Ige O \& Arinola OG (2015). Plasma vitamins and essential trace elements in newly diagnosed pulmonary tuberculosis patients and at different durations of anti-tuberculosis chemotherapy. Egypt J Chest Dis 64(3): 675-9.

30. Zuberi LM, Habib A, Haque N \& Jabbar A (2008). Vitamin D deficiency in ambulatory patients. Journal of the Pakistan Medical Association. 58(9): 482.

31. Hewison M. (2010). Vitamin D and the immune system: new perspectives on an old theme. Endocrinol Metab Clin North Am 39: 365-379.

32. Davis K, Edrisa M, Richard S, William W (2013). Vitamin D deficiency among adult patients with tuberculosis: a cross sectional study from a national referral hospital in Uganda. BMC Res Notes 6: 293.

33. Banda R, Mhemedi B \& Allain T (2010). Prevalence of vitamin D deficiency in adult tuberculosis patients at a central hospital in Malawi. Int J Tuberc Lung Dis 15(3): 408-410. 